\title{
SPRAWOZDANIE Z KONFERENCJI \\ „ZACHOWANIE CYFROWEGO DZIEDZICTWA ARCHIWALNEGO”, TORUŃ, 24-25 CZERWCA 2015 R.
}

http://dx.doi.org/10.12775/AKZ.2015.017

WKanferencja odbyła się w Collegium Humanisticum UMK w Toruniu, Historycznych UMK. W konferencji uczestniczyli: pracownicy UMK, NAC, w bardzo nielicznym stopniu pracownicy archiwów państwowych (mimo że informacja o konferencji została rozesłana do tych instytucji), przedstawiciele Naczelnej Dyrekcji Archiwów Państwowych (Andrzej Biernat i Krzysztof Politowski) oraz bibliotek, archiwów zakładowych i innych placówek.

Pierwszy dzień obrad rozpoczęli: Wojciech Woźniak (dyrektor NAC) oraz Waldemar Chorążyczewski (UMK), którzy omówili współpracę między obiema instytucjami: umowa została podpisana w styczniu 2014 r., na 3 lata (z opcją przedłużenia), jej celem jest realizacja wspólnych projektów naukowych i badawczych związanych z zagadnieniami archiwistyki cyfrowej oraz kwestiami związanymi z dokumentacją w postaci cyfrowej. W. Woźniak stwierdził, że współpraca z tak wiodącym ośrodkiem naukowym, jakim jest UMK, jest wielką szansą na zdefiniowanie problemów badawczych i zgromadzenie osób zainteresowanych tematyką; odwołał się też do statutu NAC, który przewiduje działalność naukową. Elementami współpracy są: konferencje, warsztaty, spotkania robocze, ekspertyzy, artykuły naukowe, opinie. W. Woźniak nakreślił też problemy, z którymi zetkną się archiwiści: gdzie i przez kogo będą przechowywane dane elektroniczne, np. rejestry publiczne, czy instytucje zewnętrzne będą spełniać funkcję archiwów, czy dane będą przekazywane do archiwów państwowych. W. Chorążyczewski w swoim wystąpieniu podkreślit, że wobec ogromu źródeł, z jakim spotyka się historyk (a klasyczny historyk dobrze się czuje, gdy ma do dyspozycji mało źródeł), niezbędna jest ich matematyzacja i metody statystyczne. Dodał, że istotne źródła są i będą przechowywane nie tylko w archiwach państwowych, stąd powinno się raczej mówić o zachowaniu dziedzictwa, a nie o archiwizacji. 
Problemem nie jest dychotomia: papier czy dokumenty elektroniczne, ale pytanie: jaki jest udział narzędzi technologicznych w tworzeniu źródeł.

Dyrektor Andrzej Biernat (NDAP) zastanawiał się, jak zachowywać dokumenty osobiste, podkreślił także, że obecnie jednym z głównych problemów są procesy aktotwórcze.

Wiesław Nowosad (UMK) w referacie Problemy definiowania dokumentu elektronicznego w kontekście systemów teleinformatycznych zaproponował m.in. zastąpienie pojęcia „nośnik” pojęciem „pamięć trwała”.

W dyskusji Krzysztof Politowski (NDAP) podkreślił, że postępująca legislacja prowadzi do rozmaitych komplikacji, wynikających m.in. z faktu, że definicja dokumentu elektronicznego wywodzi się z definicji dokumentu tradycyjnego, gdzie nośnik jest nierozłącznie związany z informacją. Dodał, że występuje istotna różnica między daną (bajt, litera itp.) a informacją: dana musi podlegać interpretacji - stąd z tych samych danych pochodzi różna informacja.

Następnie Halina Robótka (UMK) przedstawiła ciekawy referat $O$ potrzebie opracowania stownika dla zarzaddcy dokumentacji: wobec braku takiego słownika, i w ogóle braku słowników dziedzinowych, podjęto na UMK prace nad opracowaniem takowego: moment wydaje się dobry, bo dziedzina jest zaawansowana i można podsumować jej dorobek (okazało się, że termin „archiwistyka cyfrowa”, którego przyjęcie wzbudzało kiedyś duży opór, jest już do zaakceptowania). Prace nad słownikiem są dość zaawansowane, przeprowadzono kwerendę terminologiczną w aktach prawnych, potrzebna jest kwerenda m.in. w literaturze przedmiotu. Na razie wyniki kwerend gromadzone są w bazie danych, ale planowana jest odrębna publikacja. W założeniach prace nad słownikiem mają być kontynuowane w ramach współpracy z NAC. Jak zawsze, gdy pojawia się projekt nowego słownika archiwalnego, pada pytanie, czy NDAP prowadzi jakieś prace w tym zakresie, zważywszy na wcześniejsze zapowiedzi i projekty, a pytania te stawiane są po to, aby nie dublować prac (W. Chorążyczewski). Dyrektor A. Biernat odpowiedział, że na razie w NDAP trwają prace nad tłumaczeniem słownika międzynarodowego, podkreślił jednak, że polski słownik jest bardzo potrzebny, szczególnie wobec nowych problemów terminologicznych, których przykładem jest zachwianie zasady przynależności terytorialnej, związane z odmiejscowieniem dokumentacji elektronicznej.

Następnie Hanna Staszewska (AP w Poznaniu) i Wojciech Woźniak zaprezentowali podsumowanie ankiety „Dokumentacja elektroniczna w archi- 
wach państwowych”: 17 archiwów posiada dokumentację elektroniczną; co ciekawe, w sprawozdaniach statystycznych Kn-1 za 2014 r. posiadanie tejże wykazało tylko 10 archiwów. Archiwa przejęły ją i przechowują na różnych nośnikach (płyty CD, DVD, dyskietki, dyski) oraz w większości inwentaryzują (baza IZA, ZoSIA, ZEUS, spisy w MS Word i MS Excel). Żadne archiwum nie posiada procedur regulujących tryb postępowania z dokumentacją elektroniczną, nieliczne zaś wyraziły swoje wątpliwości co do obowiązujących przepisów o ewidencji zasobu i formularzy sprawozdawczych. Dyrektor. W. Woźniak, omawiając planowane działania NAC w zakresie dokumentacji elektronicznej, zapowiedział m.in. prace nad opracowaniem wytycznych dot. postępowania z dokumentacją elektroniczną, umożliwienie jej opisania w systemie ZoSIA oraz udział w pracach eARK i implementację ich efektów w Polsce (European Archival Records and Knowledge Preservation - międzynarodowy projekt współfinansowany przez UE, w którym uczestniczą archiwa, uczelnie i firmy komercyjne w celu stworzenia i pilotowania paneuropejskiej metodyki archiwizacji dokumentów elektronicznych). Zapowiedział też kontynuowanie wsparcia eksperckiego dla archiwów państwowych w zakresie postępowania z dokumentacją elektroniczną, administrowanie prototypem ADE (Archiwum Dokumentu Elektronicznego) oraz udział w pracach nad docelowym ADE.

Najwięcej dyskusji w tej części obrad wzbudziły kwestie postępowania z kopiami w archiwach, a więc pytanie, czy kopie cyfrowe lub kserokopie oryginalnych materiałów przechowywanych gdzie indziej można włączać do zasobu. A. Biernat uznał to za jeden z błędów metodyki (archiwum państwowe nie powinno brać odpowiedzialności za kopie, gdy oryginały są poza nim), a sztandarowym przykładem takiego postępowania jest Archiwum Akt Nowych. W odpowiedzi H. Staszewska wskazała, że archiwa czekają na wytyczne w tym zakresie z NDAP, gdzie od wielu lat trwają prace nad odpowiednim normatywem, niestety na razie bez rezultatu. Dodała, że Archiwum Państwowe w Poznaniu pozyskało kopie cyfrowe biletów meczowych klubu Lecha Poznań i włączyło je do zasobu. Zastanawiano się też, czemu tylko 17 archiwów potwierdziło obecność dokumentacji elektronicznej w swoim zasobie. Czyżby pozostałe ukryły ten fakt lub może nie wiedzą, co posiadają?

Następne dwa wystąpienia dotyczyły kwestii prawnych: Rafała Galuby (UAM): Terminologia związana z dokumentacja elektroniczna $w$ polskim prawie oraz Marka Konstankiewicza (UMCS): Archiwalia majace postać cyfrowa $w$ regulacjach prawa polskiego. $\mathrm{R}$. Galuba stwierdził, że Polska posiada najgor- 
szą ustawę o podpisie elektronicznym na świecie, co bardzo utrudnia obrót dokumentacją elektroniczną. W polskim ustawodawstwie nie oparliśmy się na dorobku państw europejskich, ale UNESCO, w dodatku nasze przepisy wprowadza się etapami, a nie kompleksowo. Wskazał na potrzebę powołania zespołu eksperckiego do czuwania nad terminologią w ustawach, stwierdził też, że terminologia urzędowa i archiwalna ma coraz mniej punktów stycznych. M. Konstankiewicz, mówiąc o odmiejscowieniu dokumentacji elektronicznej, zadał ciekawe pytanie: czy przechowywanie danych na zagranicznych serwerach to wywóz materiałów archiwalnych za granicę w rozumieniu ustawy?

W dyskusji A. Biernat stwierdził, że papier nie zostanie szybko wyeliminowany, np. akta osobowe będą prowadzone w sposób tradycyjny, nie można bowiem wymagać od pracownika posiadania kosztownego podpisu elektronicznego, aby mógł on podpisać umowę o pracę. Po raz kolejny A. Biernat podkreślił, że odmiejscowienie dokumentacji będzie miało wpływ na metodykę archiwalną.

Hadrian Ciechanowski (AP Toruń) w wystąpieniu pt. Rejestr rejestrów publicznych omówił wyniki prac zespołu UMK, który zajmuje się tym zagadnieniem: wobec braku wykazu rejestrów proponuje się stworzenie rejestru w formie bazy danych, który ma składać się z następujących 10 elementów danych: 1) nazwa rejestru, 2) zasięg (krajowy/lokalny), 3) akty prawne, na podstawie których działa rejestr, 4) instytucje prowadzące rejestr, 5) opis danych w rejestrze, 6) moment informatyzacji (data rozpoczęcia rejestru), 7) kolejne stadia informatyzacji, 8) analiza procesów archiwotwórczych, 9) adres, 10) ilość danych.

Podobną tematykę przedstawiono w referacie autorstwa Katarzyny Kaweckiej, Katarzyny Krawczyk i Michała Kubiczka (UMK): Problemy i doświadczenia związane z budowaniem opisów rejestrów publicznych, w którym omówiono rejestry: REGON (Krajowy Rejestr Urzędowy Podmiotów Gospodarki Narodowej), PESEL (Powszechny Elektroniczny System Ewidencji Ludności), CEPiK (Centralna Ewidencja Pojazdów i Kierowców) i KRS (Krajowy Rejestr Sądowy).

Po tych wystąpieniach K. Politowski (NDAP) zastanawiał się, czy należy archiwizować dane w rejestrze, czy dokumenty, na podstawie których prowadzi się rejestr. Stwierdził, że problem archiwizacji rejestru występuje w momencie jego likwidacji; dodał, że NDAP jest w kontakcie z MSW w sprawie przejęcia bazy PESEL: dane mają zostać przejęte w sposób ustrukturyzowany w postaci pliku i trafić docelowo do NAC. 
Z kolei Andrzej Anisimowicz (NAC) w prezentacji pt. Europejskie doświadczenia $w$ dziedzinie przejmowania, przechowywania $i$ udostępniania dokumentów elektronicznych - wnioski z konferencji Born-Digital: from Ingest to Access przedstawił dwie podstawowe strategie przechowywania dokumentów elektronicznych: migrację (dostęp do dokumentacji w aktualnym formacie) i emulację (dostęp w oryginalnym formacie). Następnie omówił wybrane przykłady europejskie: system EZD w Szwajcarii (5 dozwolonych formatów plików), w Austrii (w 2004 r. w całej administracji wprowadzono rozwiązanie komercyjne), we Francji (największą wadą jest wieloetapowy proces przekazywania dokumentacji elektronicznej do archiwów państwowych, a cały proces wydłuża fakt, że metadane są poprawiane przez archiwistów). W Polsce na razie brak prawdziwego systemu ADE (Archiwum Dokumentu Elektronicznego), a archiwiści nie mają wpływu na tworzenie EZD. W dyskusji K. Politowski powiedział, że archiwizacja danych cyfrowych to konieczność stojąca przed instytucjami państwowymi i powiązana z tym kwestia zaufania obywateli do urzędników: jeśli go nie ma, tworzymy składy chronologiczne i dublujemy dokumentację, także tę zeskanowaną, a - jak obrazowo stwierdził - za skanerem powinna stać niszczarka (sic!).

Następnie Krzysztof Hunia (COI) przedstawił prezentację o systemie tworzonym w Centralnym Ośrodku Informatyki MSW: E-dok i e-dok archiwum jako kompleksowe rozwiąanie archiwów w urzędach publicznych.

Anna Krzemińska (PAN Kraków) w wystąpieniu Repozytorium danych badawczych. Gdzie jest miejsce dla archiwum w modelu otwartego dostępu do danych badawczych? przedstawiła problem przechowywania danych badawczych w repozytoriach danych. Europejskie programy grantowe Horizon 2020 i Erasmus zalecają, aby były one prezentowane w otwartym dostępie i do ponownego wykorzystania. W Polsce działają repozytoria danych badawczych (np. CEON, RCIN), niektóre nie gromadzą żadnych danych, kilka gromadzi publikacje. A. Krzemińska zaproponowała, aby stworzyć projekt standardu gromadzenia i przechowywania danych badawczych w Polsce, do czego potrzebny jest spory zespół ludzi. W dyskusji podnoszono, że skoro takie repozytoria istnieją, to nie ma potrzeby tworzenia nowych, a K. Politowski wskazał wręcz na Centralne Repozytorium Informacji Publicznej, możliwe do wykorzystania.

To było ostatnie wystąpienie pierwszego dnia obrad.

Drugi dzień konferencji rozpoczęła prezentacja Justyny Soliwody (NAC) pt. Archiwizacja Internetu $w$ Polsce. Podsumowanie dziatań $i$ inicjatyw. Pre- 
legentka zwróciła uwagę na trwałość, a raczej ulotność informacji w Internecie, zastanawiała się też, czy strona internetowa to materiał archiwalny (czyli część działalności urzędów i organizacji publicznych), czy publikacja. W Polsce badania nad archiwizacją Internetu prowadzi Biblioteka Narodowa, która od 2008 r. należy do Konsorcjum International Internet Preservation Consortium (obecnie 48 członków), którego celem jest rozwój i upowszechnienie narzędzi umożliwiających archiwizację Internetu oraz opracowanie odpowiedniego oprogramowania. Wg projektu zmian w ustawie o egzemplarzu obowiązkowym strony internetowe miały być archiwizowane przez Bibliotekę Narodową, jednak projekt ten został wycofany. W Polsce praktyczną archiwizacją Internetu zajmuje się NAC, gdzie od 2009 r. działa Archiwum Internetu (działalność ta jest wpisana zarówno do rozporządzenia powołującego NAC, jak i do statutu i regulaminu organizacyjnego). Archiwum Internetu zachowuje najważniejsze, wybrane strony urzędów z domeny gov.pl: m.in. Kancelarii Prezydenta RP, Prezesa Rady Ministrów, Sejmu, Senatu, NDAP, archiwów państwowych i Muzeum Narodowego w Krakowie. Archiwizacja następuje przy użyciu narzędzi Heritrix i Wayback Machine i odbywa się co 6 miesięcy.

Następnie Agnieszka Rosa (UMK) w referacie zatytułowanym Ślad cztowieka $w$ Internecie. Zagadnienie archiwizacji od strony archiwistyki zantropologizowanej zauważyła, że Internet działa dzięki człowiekowi i dla człowieka, a jego obecność w Sieci można podzielić na oficjalną i prywatną. Główną cechą zasobów sieciowych jest ich efemeryczność i zmienność, stad istotne są strategie archiwizacji. I tak mogą się tym zajmować: instytucje narodowe rządowe (głównie biblioteki, np. brytyjska, czeska), instytucje non-profit (globalne, regionalne), archiwizacja dokonywana przez użytkowników (tematyczna) oraz samoistna przez portale czy serwisy. Popularna jest też archiwizacja problemowa, tematyczna, np. projekt September 11 Digital Archive lub Hurricane Digital Memory Bank. Co archiwizować? To, co oryginalne i unikatowe w Sieci.

Piotr Bewicz (UMK) przedstawił Problematykę archiwizacji profili administracji publicznej, osób publicznych i wydarzeń publicznych w portalach spotecznościowych, skupiając się na Facebooku i Twitterze. Twitter jest archiwizowany przez Bibliotekę Kongresu USA, gdzie codziennie trafia pół miliarda tłitów; materiały te na razie nie są udostępniane, trwają natomiast prace nad modelem ich udostępniania. P. Bewicz podkreślił znaczenie instytucji pamięci i przypomniał słowo-klucz dla archiwum, jakim jest „zdeponowanie”. Social media ze swej natury są tożsame z rzeczywistością, tym samym wymy- 
kają się działaniom archiwizacyjnym, i stąd pytanie: czy chcąc archiwizować social media, zawłaszczamy archiwum?

Następnie Marcin Frąś (UMK) przedstawił Problematykę wartości i zawartości portali hobbystycznych i profili ich użytkowników, posługując się przykładem portalu Filmweb.

Potem Bartłomiej Konopa (UMK) w referacie Strona internetowa jako materiat archiwalny dokonał systematyzacji stron, dzieląc je m.in. na statyczne i dynamiczne, przedstawił także argumenty za ich archiwizacją, z których najważniejsze jest kryterium unikatowości, oraz fakt, iż często pełnią funkcję furtki do systemu informacji urzędowej, oraz argumenty przeciw: powielanie informacji, ich niekompletność lub lakoniczność, a także brak regularnego i konsekwentnego prowadzenia.

Następnie Sonia Waleszczuk (UMK) zaprezentowała referat pt. Archiwizacja Biuletynu Informacji Publicznej, a Magdalena Wiśniewska (UMK) Cyfrowe archiwa spoteczne. Autorka omówiła najbardziej znane: Ośrodek KARTA, CATL (Cyfrowe Archiwa Tradycji Lokalnej), MIASTOGRAF.pl (Cyfrowe Archiwum Łodzian) oraz inne: Archiwum Korporacyjne, Medialne Archiwum Jana Pawła II, Bronowickie Archiwum Społeczne.

Katarzyna Kluczwajd (WBP Książnica Kopernikańska w Toruniu) przedstawiła prezentację pt. Podgórz Widmo - domowe zasoby archiwalne a kreatywne dziatania na rzecz edukacji archiwalnej, pokazując aplikację (także mobilną), z którą można zwiedzić lewobrzeżną część Torunia, mniej znaną, pozbawioną spektakularnych zabytków, ale niezmiernie ciekawą. Projekt ten stanowi przykład tworzenia społeczności skupionej wokół historii własnej dzielnicy, czego najlepszym przykładem są inicjatywy mieszkańców, chętnie udostępniających rodzinne zdjęcia i pamiątki, które po zeskanowaniu zostały wykorzystane w aplikacji.

W dyskusji podnoszono wagę potencjału tkwiącego w archiwach społecznych jako elementu budowania tożsamości i pamięci lokalnej, a nawet integracji różnych społeczności. W tym kontekście H. Staszewska przypomniała o archiwum społecznym w Michałowicach pod Krakowem, gdzie zaczęto inicjować rozmaite projekty mające na celu integrację „starych” i „nowych" mieszkańców przez wykorzystanie mikrohistorii i uczenie szacunku dla tradycji lokalnej. Przy okazji dyskusji o cyfrowych archiwach społecznych zastanawiano się (W. Nowosad, M. Konstankiewicz), czy podmiot, który gromadzi i przechowuje materiały, ale ich nie udostępnia, to jeszcze jest archiwum? H. Robótka skonstatowała, że do rozstrzygnięcia tego dylematu 
potrzebna jest definicja archiwum w ustawie archiwalnej. Odnosząc się do archiwizacji Internetu, podnoszono kwestię prawa do zapominania i prawa do zapomnienia jako opozycji do „szaleństwa” archiwizowania wszystkiego (H. Staszewska). W tym kontekście W. Woźniak przypomniał, że sami przekazujemy swoje dane i sami pozwalamy na archiwizację swoich postów czy tłitów, zgadzając się (często bezwiednie) na odpowiednie zapisy regulaminowe rozmaitych portali czy serwisów. A. Rosa podkreśliła, że ważna jest również archiwizacja reakcji w Sieci, w tym szczególnie zjawisko hejtu. Padały też stwierdzenia, że urzędy zbyt często wykorzystują social media (np. Twittera) do kontaktów z obywatelami, lekceważąc tym samym urzędowe kanały komunikacji, czyli BIP.

Następnie Katarzyna Kraft (UMK) przedstawiła studium przypadku pt. Dokumentacja elektroniczna $w$ procesie archiwotwórczym jednostek wymiaru sprawiedliwości. Na przyktadzie Sądu Okręgowego w Toruniu. Autorka skonstatowała, że zaobserwowana praktyka nie jest właściwa. W. Woźniak dodał, że przedstawione badania prowadzone są w ramach współpracy z NAC i podkreślał ich znaczenie. Radził, aby w takich przypadkach prosić o pomoc Archiwum Państwowe w Toruniu, które „z urzędu” sprawuje nadzór nad dokumentacją w sądzie.

Kolejne referaty dotyczyły spuścizn. Monika Weiss (UMK) przedstawiła temat: Dokumentacja elektroniczna $w$ narastajacych spuściznach archiwalnych (na podstawie ankiet $i$ wywiadów z pracownikami UMK). Ankieta zawierała 14 pytań, otrzymano 62 odpowiedzi (mężczyźni odpowiadali częściej). Pytano m.in. o wiek, płeć, uprawianą dyscyplinę naukową, co dana osoba rozumie przez dokumentację elektroniczną, czy wytwarza takową, jak ją chroni (czy sporządza kopie mejli), czy digitalizuje dokumentację tradycyjną (39\% odpowiedziało twierdząco), jaki ma stosunek do dokumentacji papierowej, a jaki do elektronicznej (im młodsi respondenci, tym mniej papieru wytwarzają).

Marta Różyńska (UMK) omówiła Dokumentację elektroniczna w zarchiwizowanych spuściznach na przyktadzie Stanistawa Gorgolewskiego (wybitnego fizyka), przechowywaną w Archiwum UMK. Znajduje się w niej zbiór płyt CD i 3 pendrajwy, zawierające m.in. skany artykułów, rozdziałów książek, fotografii, rachunków, opakowań po lekach itp. Prof. S. Gorgolewski kolekcjonował hobbystycznie zakrętki do butelek i skany tychże zachowano w spuściźnie. Pliki występują w wielu wersjach i w różnych formatach. M. Różyńska przedstawiła schemat systematyzacji dokumentacji w zespole, 
wykorzystując do tego celu Wytyczne Archiwum PAN i proponując opracowanie dokumentacji elektronicznej tak samo jak tradycyjnej.

Ostatnie wystąpienie, Justyny Stuczyńskiej (UMK), dotyczyło Dokumentacji elektronicznej $w$ mediach.

Podsumowując konferencję, W. Woźniak i W. Chorążyczewski stwierdzili, że przedstawiona problematyka, dotycząca różnych aspektów dokumentacji elektronicznej, jest niezwykle ważna, aktualna i skomplikowana. Podniesione tematy wymagają często dalszych badań i refleksji, wyrażono jednak nadzieję, że podjęta współpraca między NAC i UMK z pewnością przyczyni się do pogłębienia wiedzy w zakresie szeroko pojętej archiwistyki cyfrowej. Wymiernym zaś efektem konferencji będzie publikacja, w której zamieszczone zostaną przedstawione w Toruniu referaty.

* Konferencja była relacjonowana na bieżąco na Twitterze, hasztag \#cyfrowe2015.

Hanna Staszewska

(Archiwum Państwowe w Poznaniu)

\section{Konferencja „Archiwa Polski i Europy: \\ WSPÓLNE DZIEDZICTWO - RÓŻNE DOŚWIADCZENIA”}

http://dx.doi.org/10.12775/AKZ.2015.018

A rchiwa gromadzące zapisy różnych form pamięci odgrywają ważną rolę
działalność determinowana jest różnymi czynnikami. Analiza społecznych
funkcji archiwów i ich zmienności to obszerne i złożone zagadnienie. Celem
konferencji zorganizowanej w Warszawie 16 i 17 IX 2015 r. stało się rozszerze-
nie refleksji dotyczącej wybranych problemów związanych z tym zjawiskiem.
Znalazły się wśród nich: 1 . Dobra kultury w przestrzeni publicznej. Polityka 